\title{
CRIMINALIZATION WITHOUT PUNISHMENT
}

\author{
James Edwards*
}

What is the relationship between a theory of permissible criminalization and a theory of permissible state punishment? Some claim that the former theory must be derived from the latter. According to these writers, if we want to identify the conditions under which it is permissible to criminalize, we must first identify the conditions under which it is permissible for the state to punish. ${ }^{1}$ The latter set of conditions doubles as part of the former set. Let us call this the punishment thesis. Michael Moore has suggested that the punishment thesis represents a 'new orthodoxy' in the literature on criminalization. ${ }^{2} \mathrm{My}$ aim in this paper is to explore what can be said for this new orthodoxy.

Two prominent defenders of the punishment thesis are Moore and Doug Husak. According to Husak, 'the most basic question to be answered by a theory of criminalization is: For what conduct may the state subject persons to punishment? ${ }^{3}$ In his view:

Before legislators enact a criminal offense, they had better be confident that the state would be justified in punishing persons who breach it. The state should not create crimes that will subject offenders to punishment without good reason to believe that the punishment to which such persons will become subject would be justified. If the punishment of those who commit a given offense cannot be justified, the state should not have enacted that offense in the first place. ${ }^{4}$

\footnotetext{
* Thanks to Doug Husak, Chloë Kennedy, Ambrose Lee, Patrick Tomlin, an anonymous reviewer for Legal Theory, and audiences at Edinburgh University and the London School of Economics.

${ }^{1}$ As these remarks suggest, my focus here is on criminalization and punishment in municipal legal systems.

${ }^{2}$ Michael Moore, A Tale of Two Theories, 28 Criminal Justice Ethics 27 (2009), at 37.

${ }^{3}$ DOUGLAS HUSAK, OVERCRIMINALIZATION (2008), at 82 (emphasis in the original).

${ }^{4}$ Id. at 78.
} 
Husak argues for the existence of seven constraints on permissible state punishment. These constraints 'constitute the substance of a theory of criminalization'. ${ }^{5}$ Criminal laws that 'fail to satisfy' each constraint 'will make offenders eligible for punishments that cannot be justified'. Husak claims that '[n]o respectable theory of criminalization should tolerate this result'. ${ }^{6}$

Though Moore disagrees with Husak about the conditions of permissible state punishment, the two agree on 'the implications of a theory of punishment for a theory of criminalization'. ${ }^{7}$ Husak, Moore writes, 'derives his theory of the latter from his theory of the former as tightly as do I'. ${ }^{8}$ When it comes to criminalization, Moore claims that 'only morally wrongful behaviors should be criminalized'. ${ }^{9}$ In his view this constraint 'can be seen to follow from a retributivist theory of punishment', which insists that only morally wrongful conduct is permissibly punished. ${ }^{10}$ We will return to why this might be thought to follow. But enough has been said to show that Husak and Moore both endorse the punishment thesis. They agree that whether ping is permissibly criminalized depends on whether ping satisfies the conditions of permissible state punishment.

The following sections consider what argument might be given for the punishment thesis. Before we proceed to those arguments, some clarifications are in order.

(a) Permissibility - an action is impermissible, for present purposes, if it is wrongful to perform it. An action is permissible if it is not impermissible. Different actions may be (im)permissible by the lights of different normative systems. Actions may be legally impermissible but morally permissible, or morally impermissible but legally permissible. References in what follows to permissibility simpliciter are references to moral permissibility.

\footnotetext{
${ }^{5}$ Douglas Husak, Reservations About Overcriminalization, 14 New Criminal Law Review 97 (2011), at 103.

${ }^{6}$ HUSAK, supra note 3 , at 82.

${ }^{7}$ HUSAK, supra note 3, at 197; Moore, supra note 2, at 36.

${ }^{8}$ Moore, supra note 2, at 36.

${ }^{9}$ Id. at 32 .

${ }^{10} I d$.
} 
(b) Punishment - two questions about punishment should be distinguished. First, what is it to punish? Second, when is punishment permissible? My principal concern here is not with the answer to either question. It is with the relationship between the conditions of permissible punishment and the conditions of permissible criminalization. More precisely, it is with whether the punishment thesis accurately captures that relationship. It is difficult, however, to evaluate the punishment thesis without saying something about punishment itself. To beg as few questions as possible, let us restrict ourselves to some familiar points.

A punishes $\mathrm{B}$ only if $\mathrm{A}$ acts for certain reasons. A must act for the reason that (i) A's action will harm B, and (ii) B violated some norm. We need condition (i) to explain why quarantine and civil commitment are not (normally) punishments. To see the importance of condition (ii), consider a case in which A intentionally harms $\mathrm{B}$ by spreading rumours about her. A knows nothing about $\mathrm{B}$ other than that $\mathrm{B}$ is competing with $\mathrm{A}$ for a job. She simply thinks that spreading the rumours will reduce B's chances and increase her own. It seems clear that-all else being equal-A is not punishing $\mathrm{B}$. Things would be different if $\mathrm{A}$ were to spread the rumours because of some perceived slight. This would be to intentionally harm B for the reason that B violated some norm. But this only helps to confirm the importance of condition (ii): we need that condition to distinguish punishment from other cases in which B is intentionally harmed.

We can leave open whether the conditions I have identified are sufficient to distinguish punishment from related phenomena. They are, however, necessary conditions that many accept. ${ }^{11}$ I will assume their truth in what follows. As to permissible punishment, there are two conditions on which Husak and Moore agree: $^{12}$

(W): it is permissible to punish B for ping only if ping is morally wrongful;

\footnotetext{
${ }^{11}$ For defence, and references to other defenders, see BOONIN, THE PROBLEM OF PUNISHMENT (2008), at 12-23.

${ }^{12}$ HUSAK, supra note 3, at 83; Moore, supra note 2, at 31.
} 
(D): it is permissible to punish B for ping only if ping is deserving of punishment.

Not all wrongful actions make one deserving of punishment. Most obviously, wrongful actions may be excused. ${ }^{13}$ Satisfaction of the condition in (W) thus does not entail satisfaction of the condition in (D). In what follows, I will assume the truth of both (W) and (D). Why these conditions in particular? First, I already mentioned that both (W) and (D) are accepted by the most prominent defenders of the punishment thesis. To assume (W) and (D) is thus to concede to those defenders part of the theory of punishment they accept. If the punishment thesis fails despite the concession, its defenders must either give up the thesis, or give up part of their theory of punishment. Second, (W) and (D) are widely accepted. Husak writes that they are compatible with virtually all theories of punishment that philosophers have tried to defend' ${ }^{14}$ No doubt this is too strong. But if it is even close to the truth, my discussion should be of interest to those with a wide range of views about permissible punishment.

(c) Criminalization - to criminalize is not to punish. Nor does criminalizing ping entail that anyone will be punished for having ped. Many propose, however, that to criminalize ping is to create liability to state punishment. For Husak, this is 'something approximating a conceptual truth'. ${ }^{15}$ Liability, as I understand it here, is a legal notion. To be liable to state punishment for ping is for state officials (or some of them) to have the legal power to punish one for having $\varphi$ ed. One might claim that officials often have no such power unless certain procedural conditions are met-unless B pleads guilty as charged, or is found guilty at the conclusion of a criminal trial. If this is correct, we should modify the above proposal in the following way. Criminalization of $\varphi$ ing makes it the case that $B$ is liable to punishment if and only if B pleads guilty to, or is found guilty of, having

\footnotetext{
${ }^{13}$ Justified actions, on the other hand, are not wrongful. Moore explicitly accepts this: see MICHAEL MOORE, PLACING BLAME (1997), at 673-674.

${ }^{14}$ HUSAK, supra note 3, at 83.

${ }^{15}$ Id. at 78 .
} 
ped in a criminal court. Though this way of speaking may be more accurate, ${ }^{16}$ it is also more cumbersome. For simplicity, I will simply say that to criminalize $\varphi$ ing is (among other things) to create liability to punishment for having $\varphi$ ed.

In what follows I will assume the truth of the proposal with which the previous paragraph began. ${ }^{17}$ Before moving on, it is worth noting an ambiguity in the term criminalization. Is ping criminalized if and only if ping is made a criminal offence, or is ping criminalized if and only if it is made a crime? This is not a distinction without a difference. An action is a crime only if it is both a criminal offence and no defence is available to those who so act. ${ }^{18}$ In what follows, I assume that, for the purposes of the punishment thesis, to criminalize is to make ping a crime. This must be Husak's view. For him, ping is permissibly punished only if ping deserves punishment. This is (D). If we add the punishment thesis, it follows that ping is permissibly criminalized only if ping is deserving of punishment. Now imagine that to criminalize is to make something a criminal offence. Husak would then have to say that it is impermissible to make it a criminal offence to assault others under duress - even if a defence of duress is available-

16 'May' because on an alternative view, officials have the power to punish people who have committed crimes whether or not procedural conditions are met. Those conditions determine whether exercising that power is legally permissible, not whether the power exists at all.

${ }^{17}$ It is worth briefly noting that the proposal's truth is far from obvious. There certainly appear to be criminal sentences that fail to satisfy the conditions I earlier labeled (i) and (ii). One candidate is the sentences imposed in many legal systems on so-called dangerous offenders. These sentences are to be imposed for the reason that doing so will 'protect the public'. It is true that such sentences are properly imposed only on condition that B was convicted of a crime. But satisfaction of this condition is not the reason for B's sentence. B is to be deprived of liberty not because B violated some norm, but because B is a dangerous individual against whom others need to be protected. It is true, of course, that B's criminal act is taken to be evidence of B's dangerousness. But it remains the case that it is the dangerousness-B's propensity to act in certain ways in the future- not the norm-violation-something B did in the pastthat provides the court's reason for sentencing B. It is far from clear that if a legislature creates liability to such sentences—and only to such sentences—it has not criminalized.

${ }^{18}$ I am grateful to Patrick Tomlin for discussion of this point. 
because those who assault under duress do not deserve punishment. We should not saddle Husak with such an implausible view.

(d) The punishment thesis - it is worth clarifying two aspects of the punishment thesis at this stage. First, that thesis does not hold that all necessary conditions of permissible criminalization are necessary conditions of permissible punishment. It is consistent with there being conditions of the former that are not conditions of the latter. Whether there are such conditions is a further question. Second, the punishment thesis does hold that the necessary conditions of permissible state punishment are necessary conditions of permissible criminalization. But that claim must be clarified if it is not to be misunderstood. To see why, notice that the following are both plausible conditions of permissible state punishment: the state may punish B for ping at $t$ only if (iii) ping is already a legal wrong at $t$, and (iv) it was proved in court that B ped, or B was entitled to require such proof and declined to require it. Neither (iii) nor (iv), however, is a plausible condition of permissible criminalization. To criminalize ping is, inter alia, to make ping a legal wrong. So ping need not already be a legal wrong if it is to be permissibly criminalized. Nor is anyone entitled to require proof that they $\varphi$ ed before $\varphi$ ing can permissibly be made a crime. This may seem to suggest that the punishment thesis is itself implausible. But that would be too quick. A plausible version of the punishment thesis imposes a more modest requirement: $\varphi$ ing is permissibly criminalized only if ping satisfies the necessary conditions of permissible state punishment once criminalized. As long as the presumption of innocence is adhered to, (iii) and (iv) are automatically satisfied once ping becomes a crime. I will assume in what follows that this is the case. Other conditions of permissible punishment, however, are not so easily met. Consider (W). Sometimes criminalization can help make it the case that this condition is satisfied. ${ }^{19}$ But Moore and Husak both deny that (W) is automatically satisfied by criminalization.

\footnotetext{
${ }^{19}$ The rules of the road are the classic example. Once we have rules of this kind, failing to follow them will often be to violate 'antecedently existing moral norms against risking harm to others'. So it will often be morally wrongful to fail to follow the rules. See MOORE, supra note 13, at 73; HUSAK, supra note 3, at 103-119. Husak doubts that are many cases in which the law makes a moral difference of this kind. But he does not deny that there are some.
} 
This is surely correct. So there are conditions of permissible punishment which ping may fail to meet even after ping is criminalized. According to the punishment thesis, this failure is incompatible with permissible criminalization.

What argument can be given for the punishment thesis? Consider the following:

(1) To criminalize ping is to create liability to state punishment for $\varphi$ ing;

(2) It is permissible to create liability to state punishment for ping only if it is permissible for the state to punish people for ping;

(3) Therefore, it is permissible to criminalize ping only if it is permissible for the state to punish people for ping.

This argument is valid, and we are assuming the truth of (1). So we should focus on (2). To properly evaluate (2), we must draw some distinctions. Notice first that (2) identifies a constraint, and that constraints are principles of the following form:

(C): $\mathrm{x}$ is a necessary condition of the permissibility of $\mathrm{y}$.

In (2), $\mathrm{y}$ is the creation of liability to state punishment; $\mathrm{x}$ is its permissible imposition. We can distinguish between two ways in which constraints might be defended. According to the first:

(v) There is no reason to do y unless $\mathrm{x}$;

(vi) It is permissible to do y only if there is reason to do $y{ }^{20}$

(vii) Therefore, it is permissible to do $\mathrm{y}$ only if $\mathrm{x}$.

Let us call this the argument from reasons. According to the second defence:

(viii) The reasons to do y are defeated unless $\mathrm{x}$;

${ }^{20}$ This is not, of course, true of all act-types. But it is true of some. Killing is an obvious example. 
(ix) It is permissible to do y only if there is undefeated reason to do y;

(x) Therefore, it is permissible to do y only if $\mathrm{x}$.

Let us call this the argument from defeaters. Unlike those who offer the first, those who offer the second argument need not claim to have identified the conditions under which there is reason to do y. They need only claim that whatever those reasons are, they cannot survive defeat in the absence of $\mathrm{x}$.

A number of writers defend their favoured constraints on criminalization using the argument from reasons. In Harm to Others, Joel Feinberg claims that there is reason to criminalize only if criminalization is necessary to prevent harm or serious offense to others. These preventive considerations 'exhaust the class of morally relevant reasons for criminal prohibitions'. Other putative reasons-including 'paternalistic and moralistic considerations'- 'have no weight at all'. ${ }^{21}$ Because it is wrongful to criminalize if there is no reason to do so, ${ }^{22}$ Feinberg concludes that criminalization is impermissible whenever it is not necessary to prevent harm or serious offense to others.

Husak sometimes writes as if he endorses (2) because he endorses the argument from reasons. One of his seven constraints on state punishment holds that it is only permissible for the state to punish people for wrongs that violate the shared values of the community. Following Antony Duff, he calls these public wrongs. ${ }^{23}$ Husak also writes that 'private wrongs give us no reason to criminalise in the first place; there is nothing to defeat'. ${ }^{24}$ This might be taken to suggest that in Husak's view, there is no reason at all to criminalize - and thus to create liability to state punishment—unless the conditions of permissible state punishment are met. This is, however, hard to reconcile with other

${ }^{21}$ JOEL FEINBERG, HARM TO OTHERS (1984), at 14-15.

22 This claim might be defended in several ways. I will mention just one: we already saw that criminalization confers power on state officials; the risk of this power being misused makes criminalization wrongful if there is no reason to criminalize.

${ }^{23}$ HUSAK, supra note 3, at $136 \mathrm{ff}$.

${ }^{24}$ Douglas Husak, Polygamy, in CRIMINALIZATION: THE POLITICAL MORALITY OF THE CRIMINAL LAW (R.A. Duff, Lindsay Farmer, S.E. Marshall, Massimo Renzo \& Victor Tadros eds., 2014). 
things he says. In Overcriminalization, Husak argues that we have a right not to be punished by the state, and that 'rights are valuable moral considerations that withstand countervailing utilitarian reasons' ${ }^{25}$ The right not to be punished withstands such reasons unless all seven constraints are met. Now if there are 'ordinary utilitarian reasons' to punish conduct that is not permissibly punished — including private wrongs—-there must also be reasons of this kind to criminalize such conduct. Husak appears to accept this when he writes that 'some kinds of reason'-including 'ordinary utilitarian reasons'-are not 'sufficient to justify a criminal offense'. ${ }^{26}$ While those reasons may be sufficient to justify discouraging, or even proscribing, the eating of doughnuts, they are not 'good enough' to justify making this a crime. ${ }^{27}$ To say that a reason is not 'good enough', or not 'sufficient', is to impliedly accept that it exists. And to accept this is to reject the argument from reasons. It is to accept that there sometimes is reason to create liability to punishment for ping-to do y-even if imposing state punishment for $\varphi$ ing is impermissible — even if, that is, $\mathrm{x}$ does not obtain.

Whatever Husak's view, there are independent grounds on which to think that (2) cannot be defended using the argument from reasons. To see why, imagine it becomes apparent that people are routinely being harmed by pharmaceutical products. One possible response is to impose criminal liability on manufacturers who use unsafe ingredients, or adopt unsafe manufacturing processes, and who ought to realize that their ingredients or processes are unsafe. Such liability, let us assume, satisfies both (W) and (D). This response nonetheless has its drawbacks. One is the possibility of error. Some manufacturers may not realize what they are doing is unsafe: they may underestimate the dangers created by their ingredients, or overestimate the ability of their processes to counteract those dangers. Significant harm may be done to their consumers as a result. Another drawback is the absence of guidance. What counts as safe? There are many borderline cases. When an ingredient or process sits at the borderline, manufacturers lack assurance that they will not be found criminally liable if they use it. Finally, there is the possibility of abuse. Because it is not always clear how standards of safety will be applied, unscrupulous officials may use the prospect of conviction and punishment to harass

\footnotetext{
${ }^{25}$ HUSAK, supra note 3, at 103.

${ }^{26} I d$. at 100.

${ }^{27} \mathrm{Id}$. at 102 .
} 
those they dislike, or obtain competitive advantages for those who will repay their generosity.

These drawbacks might prompt a different response. We might instead criminalize use of any ingredient or process found on an authoritative list. To avoid criminal liability, manufacturers would no longer need to rely on their own judgments of safety. To avoid conviction and punishment, they would no longer need to anticipate equivalent judgments made by prosecutors and courts. Imagine we opt for the authoritative list. As long as manufacturers keep evidence of their ingredients and processes, officials are less able to hold the prospect of criminal conviction over their heads. Manufacturers who keep up to date with the list are not at risk of being ambushed by criminal liability. And if the compilers of the list generally have better judgment when it comes to safety than manufacturers, the list is less likely to result in the mistaken use of unsafe ingredients. The aforementioned worries about abuse, guidance and error are correspondingly reduced. These reductions are themselves reasons to opt for the authoritative list.

None of this is to deny that the second response has drawbacks of its own. Not all manufacturers are alike, and some may have sufficient expertise to safely use ingredients or processes from the list. ${ }^{28}$ Their doing so may even make products cheaper, to the advantage of consumers. It is hard to see why use of this kind is morally wrongful or deserving of punishment. Some have nonetheless striven to persuade us that it is. One strategy appeals to arrogance. ${ }^{29}$ But there is nothing arrogant about using an ingredient or process which one has the expertise to make safe. Another strategy appeals to the unfairness of benefiting from the restraint of others without restraining oneself. ${ }^{30}$ But the fact that some refrain from ping dangerously_-such that their restraint benefits others-

\footnotetext{
${ }^{28}$ One might ask why expert manufacturers would not simply be exempted from liability. There are two ways this might be done: (i) granting licenses to experts, or (ii) granting experts a defence to liability. There are reasons not to pursue either option. Licensing schemes are costly to set up and administer. An expertise defence reintroduces the problem of error mentioned in the text.

${ }^{29}$ R.A. Duff, Crime, Probibition and Punishment, 19 Journal of Applied Philosophy 97 (2002).

${ }^{30} \mathrm{~K}$ Wellman, Rights Forfeiture and Mala Probibita, in THE CONSTITUTION OF THE CRIMINAL LAW

(R.A. Duff, Lindsay Farmer, S.E. Marshall, Massimo Renzo \& Victor Tadros eds., 2014).
} 
does not make it unfair for others to $\varphi$ when their doing so is safe; all the more so when their ping actually benefits others by reducing their costs.

If we opt for the second response-for the authoritative list—we make some people liable to punishments that are not permissibly imposed. ${ }^{31} \mathrm{I}$ have not tried to show that we are justified in doing this. I have merely tried to show that there are reasons to do it. One may say that my example shows little as it concerns one particular specialist activity. But the considerations on which I relied apply much more generally in criminal law. Whether a given action is a morally wrongful-and whether it is deserving of punishment - depends on moral norms that exist apart from the law, many of which are vague at the margins. Legal norms that replicate such moral norms will generate many borderline cases. Their application will often be hard to predict. Because of how costly criminal liability can be for those who become liable, there are reasons for offencedefinitions to draw clearer lines than those drawn by the aforementioned moral norms. Such lines give potential offenders greater assurance that they will not be ambushed by the criminal law. They may also protect against official abuse. But to draw such a line is necessarily to suppress some of the moral particulars: it is to make criminal liability insensitive to some of the morally salient facts that generate borderline cases. Criminal laws that are insensitive to these facts will not track the distinction between that which is, and that which is not, morally wrongful and deserving of punishment. ${ }^{32}$ The upshot is

\footnotetext{
${ }^{31}$ Assuming, as we are throughout, that Husak and Moore are correct that (W) and (D) are conditions of permissible punishment. Husak describes expert manufacturers of the kind I have described as epistemically privileged: HUSAK, supra note 3, at 155-6. They know their conduct does not create the risks that justify imposing criminal liability on others. He appears to think that making these offenders liable to punishment is consistent with the punishment thesis, because it is sometimes the only way further to substantial state interests, such as reducing harm done to consumers. But this does not establish that epistemically privileged offenders are permissibly punished, because it does not show that their conduct is morally wrongful or deserving of punishment, and Husak claims that (W) and (D) are both conditions of permissible state punishment.
}

${ }^{32}$ Consider the following example. Some crimes — theft, sexual assault and murder, for instance-can be committed only if B has certain intentions. What should intention mean for these purposes? Should B be held to have intended $\mathrm{X}$ only if $\mathrm{B}$ acted in order to bring $\mathrm{X}$ about? Or should it also be possible to find 
that there is sometimes reason to make people liable to state punishment for ping even though it is not permissible to punish them for having ped. One need not be a utilitarian to think that such reasons exist-that enhancing guidance, reducing error and combating abuse are themselves reasons for criminalization.

One might reply that where there is reason to draw a line of the kind just mentioned it is morally wrongful to violate it. In responding to this, we need not deny that offencedefinitions can make a moral difference. Some result in valuable forms of co-ordination, the value of which can indeed create moral reasons not to offend. But it is not always morally wrongful to commit offences that have this kind of value. As we saw above, some people have the expertise to be able to offend without putting others in danger or putting public goods at risk. And there are cases in which we have moral reasons to offend which defeat any reasons to comply with the law. It might be said that there is no reason not to grant defences in such cases. But this is not so. Many legal systems do not contain a general defence of moral justification. English law, to take one example,

that $\mathrm{B}$ intended $\mathrm{X}$ if $\mathrm{B}$ appreciated that $\mathrm{X}$ was a virtually certain result of her actions? If this should be possible, should appreciation of this kind be sufficient for intention? Or should there be some additional hurdle that must be cleared before B can be held to have intended X? If so, what should that hurdle be? And what about cases where B appreciates that X would be virtually certain if only B were more competent, or appreciates that $\mathrm{X}$ is highly likely to occur, or intends to make $\mathrm{X}$ highly likely? Should cases of this kind ever-and if so, under what conditions - count as cases of intention? It is far from clear that these questions can be (confidently) answered by appeal to the norms that pick out theft, sexual assault and murder as pre-legal moral wrongs. For the reasons given in the text, we have reason to craft criminal offences that draw a clearer line. We might, for instance, require that B either acts in order to bring $\mathrm{X}$ about or appreciates that $\mathrm{X}$ is virtually certain to result from her actions. To do this, however, is to make offenders out of some people whose conduct clearly is morally justified, and, equally clearly, is not deserving of punishment. If throwing one's baby out of an attic window is the only way to save her from an approaching fire, the fact that one knows death is virtually certain to result does not make one's conduct wrongful or culpable. The suggested definition of intention, however, has it that the father intends death: it suppresses the morally salient facts that make the father's conduct morally permissible. 
contains no general defence of necessity, ${ }^{33}$ and requires that defensive force be used only against threats of imminent harm. ${ }^{34}$ One reason for these limitations is to reduce the risk of error. The imminence requirement, for instance, is designed to make it less likely that force will be used against threats that turn out to be only apparent, or against genuine threats that turn out not to necessitate the use of force. The aforementioned limitations also help provide assurance that others will behave in certain ways. A general defence of necessity would permit us to trade off our legal duties against the advantages of noncompliance: when those advantages were great enough, and could not be achieved in other ways, offending acts would be legally permitted. But the more trading-off each of us does, the less reliable legal rules are as a guide to how others will behave. Particularly when it comes to rules that help co-ordinate behaviour-such as rules of the road, or those of property-diminished assurance is to be regretted. If this is correct, we have reasons not to grant defences to some people whose conduct is morally justified. ${ }^{35} \mathrm{We}$ have reason to make people liable_-across the criminal law_-to punishments that cannot permissibly be imposed.

Let us return to (2):

(2) It is permissible to create liability to state punishment for ping only if it is permissible for the state to punish people for $\varphi$ ing;

We have been considering the argument that there is no reason to create the liability mentioned in (2) unless state punishment is permissible. I have suggested that this argument fails. But (2) might instead be defended using what I earlier called the argument from defeaters. One might argue, that is, that whatever reasons there are to create liability to state punishment, those reasons are defeated unless it is permissible for the state to punish B for ping. We can distinguish between two explanations of why defeat

\footnotetext{
${ }^{33}$ In Nicklinson, [2013] EWCA Civ 466, the Court of Appeal explicitly stated that there is no such general defence. Re A (Children), [2000] 4 All ER 961 was held to be an exceptional case that did not suggest otherwise.

${ }^{34}$ Devlin v. Armstrong, [1971] NI 13.

${ }^{35}$ Either because it is the lesser of two evils between which the offender had to choose, or because it is a reasonable response to a non-imminent threat of violence.
} 
might occur. First, because liability to impermissible punishment has bad effects. Second, because liability to impermissible punishment is bad irrespective of its effects. An argument for (2) that relies on the first possibility I will call an instrumental argument. An argument that relies on the second I will call an intrinsic argument. In the next two sections, I consider arguments of both kinds.

Consider again the argument set out at the beginning of section II:

(1) To criminalize $\varphi$ ing is to create liability to state punishment for $\varphi$ ing;

(2) It is permissible to create liability to state punishment for ping only if it is permissible for the state to punish people for ping;

(3) Therefore, it is permissible to criminalize ping only if it is permissible for the state to punish people for $\varphi$ ing.

This section considers an instrumental argument for premise (2). It runs as follows: ${ }^{36}$

(A) If people are made liable to impermissible punishment, then impermissible punishments will be imposed;

(B) Doing that which results in impermissible punishments being imposed is itself impermissible;

(C) Therefore, it is permissible to create liability to state punishment for ping only if it is permissible for the state to punish people for ping;

To evaluate this argument we need to make (A) and (B) clearer. We need to distinguish between different explanations of what makes a punishment impermissible. We can begin with the following:

\footnotetext{
${ }^{36}$ Moore seems to have something like this argument in mind. He writes that it 'follows from retributivism' that only morally wrongful conduct should be criminalized, and that this follows because retributivism 'limits punishment away from the non-deserving as much as it demands punishment of the deserving' - see Moore, supra note 2, at 31.
} 
Fact-relative sense: punishments are impermissible in virtue of the fact that the substantive conditions of permissible punishment are not in fact met.

Assume again that (W) and (D) identify two such conditions. Punishments are impermissible in the fact-relative sense if those who are punished did not act wrongfully and do not deserve punishment. (A) then holds that if people are made liable to punishment for conduct that is not wrongful or deserving of punishment, some people will be punished whose conduct was neither of those things.

There is an obvious response to (A): in a perfect world, no-one would offend and noone would be punished. (A) would then be false. Husak invites us to live with him in the real world. 'When criminal laws are enacted', he writes, 'it is nearly inevitable that some punishments will need to be imposed'. This is so because some 'will persist in the prohibited behavior, whatever the law may say'. ${ }^{37}$ Now it is not clear what 'need' Husak has in mind here. It cannot be a legal need: prosecutors are not legally required to prosecute those who commit crimes; judges are often permitted to discharge those who have been convicted. Husak might instead have in mind that punishments need to be imposed if law-makers are to achieve their aims. That depends, however, on what those aims are. It is true that one possible audience for criminal laws is those who will not conform to the law unless they are likely to be punished. Absent some elaborate deception, getting these people to conform does require imposition of some punishments. But those who extend the law beyond the act-types mentioned in (W) and (D) may have a different audience in mind. They may be aiming at those who will conform to the lawwhether or not punishment is in the offing-if only they are able to work out how to do so. ${ }^{38}$ The aim may be to increase the ability of such people to conform when they try,

\footnotetext{
${ }^{37}$ HUSAK, supra note 3, at 78.

38 This second audience is comprised of Hart's 'puzzled' or 'ignorant' persons: see H.L.A. HART, THE

CONCEPT OF LAW (3d ed. 2013), at 40.
} 
and to make it the case that conformity benefits both them and others. ${ }^{39}$ The achievement of this aim does not necessitate that anyone is punished. ${ }^{40}$

That there is no need for punishment does not imply that no-one will be punished. So let us join Husak in the real world. Here, compliance with the law is almost inevitably imperfect. Nor do prosecutors and judges always prosecute and punish within the limits set by (W) and (D)—some ignore, or make mistakes about, those limits. In this world some impermissible punishments will be imposed if people are made liable to them. But if this is how we interpret (A), (B) is too strong. In a world of imperfect compliance, populated by error-prone judges and prosecutors, any instance of criminalization will result in some punishments that are impermissible in the fact-relative sense. In such a world, (B) is consistent only with the criminal law's abolition.

Because Husak and Moore are not abolitionists, this cannot be what they have in mind. (A) and (B) might, however, be modified as follows:

(A')If people are made liable to punishments that cannot permissibly be imposed then more impermissible punishments will be imposed;

(B') Doing that which results in more impermissible punishments being imposed is itself impermissible.

More than what? More, presumably, than would be imposed if people were only made liable to punishments that can permissibly be imposed in the fact-relative sense. Is ( $\mathrm{A}^{\prime}$ )

\footnotetext{
${ }^{39} \mathrm{By}$, for instance, making it the case that conformity protects conformers against abuse, and reduces the risk of harm to others. See the pharmaceutical example discussed in section II.

${ }^{40}$ Husak might have in mind a moral need to punish pers once ping is criminalized. But he does not make clear what this moral need would be. At one point, he writes that for the state not to punish some class of criminalized conduct would be for the state to 'neglect its own proscriptions' (HUSAK, supra note 3, at 78). Now $\varphi$ ing is proscribed if and only if there is a legal duty not to $\varphi$. For Husak, a proscription is part of the criminal law only if judges have a legal power to punish those who breach the aforementioned duty. It is not clear why failing to exercise the power entails that one is neglecting the duty, or why this failure is always morally problematic.
} 
correct? Not obviously. I already mentioned the discretion available to prosecutors and sentencing judges. Even if we leave this aside, $\left(A^{\prime}\right)$ might be denied. Consider again the pharmaceutical example introduced in section II. There, I distinguished two responses to the problem of harmful pharmaceutical products. The first response requires prosecutors and courts to decide whether manufacturers used ingredients or processes that are unsafe, and whether they ought to have known this was the case. The second response merely requires prosecutors and courts to decide whether manufacturers used ingredients or processes from an authoritative list. I assumed that this second response would make some people liable to punishment whose conduct does not satisfy (W) and (D). The first response, I assumed, eliminates this liability. But that response also invites prosecutors and courts to make certain moral judgments. Who ends up being punished depends on how those judgments are made. Faced with consumers who have been harmed, it may be tempting to assume that safety must have been lacking, and that manufacturers must have taken their eyes off the ball. If such assumptions are made, punishments may be too quickly imposed on those who- - having taken due care-do not deserve them. These are punishments that a suitably circumscribed list might prevent. ${ }^{41}$ The upshot is that both responses to the problem of harmful pharmaceuticals have the potential to result in (and prevent) some impermissible punishments. Which would result in more such punishments is an empirical question, the answer to which depends, among other things, on the moral (in)sensitivities of legislators, manufacturers, prosecutors, jurors and judges. Precisely because the truth of $\left(A^{\prime}\right)$ is contingent in this way, the support (A') lends to the punishment thesis is equally contingent.

Let's imagine I am wrong about this. We may still have our doubts about (B'). If we are not abolitionists, we must believe that the goods produced by criminalization can justify the imposition of some punishments that are impermissible in the fact-relative sense. To endorse $\left(\mathrm{B}^{\prime}\right)$ is to claim that while those goods do justify the number of impermissible punishments that inevitably result from liability to permissible punishment, nothing justifies the additional impermissible punishments that result from liability to impermissible

\footnotetext{
${ }^{41}$ As I claimed above, the list also gives potential offenders better guidance about what counts as an offence. Fewer offences might be committed as a result, and fewer people might be punished. So even if the proportion of punishments that is impermissible in the fact-relative sense turned out to be larger, the total number of such punishments might still be smaller if we opted for the authoritative list.
} 
punishment. But why not? Compare two views one might have about the goods that justify having criminal law in the first place. On one view those goods are preventive: what justifies having criminal law is that it results in less harm and/or fewer wrongful acts. On another view those goods are curative: what justifies having criminal law is that it results in more wrongdoers discharging duties they incur in virtue of wrongdoing. ${ }^{42}$

Start with the preventive view. If this view is sound-and abolitionism is to be rejected-preventive goods must be capable of justifying the imposition of some impermissible punishments. I claimed above that criminalizing conduct for which people are not permissibly punished can sometimes prevent harm to others, as well as some wrongful acts. This, I claimed, may be true of the authoritative list of pharmaceutical ingredients and processes, and of the imminence requirement in self-defence. ${ }^{43}$ Let us assume, for the sake of argument, that these rules result in more impermissible punishments being imposed. Non-abolitionists must claim that some amount of prevention is capable of justifying the imposition of some impermissible punishments. So why should the additional prevention achieved by the authoritative list, or the imminence requirement, never be capable of justifying more such punishments? Unless there is an answer, we should reject $\left(B^{\prime}\right)$. Things are no better if one endorses the curative view. On that view-abolitionism aside-curative goods must be capable of justifying the imposition of some punishments that are impermissible in the fact-relative sense. Prevention is better than cure. ${ }^{44}$ So prevention must also be capable of justifying some punishments of this kind. Let's say that preventing some amount of harm, $h$, can justify some number of impermissible punishments, $n$. Now imagine that criminalizing conduct which cannot be permissibly punished is both necessary to achieve $h$ and comes at the

\footnotetext{
${ }^{42}$ One might, of course, endorse a mixed view. But that makes no difference here.

${ }^{43}$ It is worth repeating that an act may be wrongful even if excused. So preventing people who believe it is necessary to use force from using force that is in fact unnecessary is still preventing wrongful (though excused) acts.

${ }^{44}$ All else being equal, it is better to prevent someone being harmed or wronged than to allow them to be harmed or wronged and then hold the harmdoer or wrongdoer responsible later.
} 
cost of $n$. The non-abolitionist who endorses the curative view cannot claim that criminalization is impermissible simply in virtue of $n \cdot{ }^{45}$ So she must also reject $\left(\mathrm{B}^{\prime}\right)$.

So far I have treated all punishments that are impermissible in the fact-relative sense as if they are alike. It might be said that this is a mistake. It might be said that there is a morally significant distinction between the impermissible punishment of those who are criminally liable, and the impermissible punishment of those who are not. Why is this distinction morally significant? One answer has it that while punishments of the latter kind are a regrettable side-effect of criminalization, punishments of the former kind are punishments that those who criminalize intend. Another answer has it that those made liable to impermissible punishment—and later punished-are used by law-makers, whereas those who are not liable at all—even if punished—are not so used. These claims suggest a further modification of $(A)$ and $(B)$ :

(A") To make people liable to punishments that cannot permissibly be imposed is (i) to make it the case that impermissible punishments will be imposed and (ii) to do so intentionally, or in a way that uses those impermissibly punished;

(B") Intentionally making it the case that impermissible punishments will be imposed, and/or using those impermissibly punished, is itself impermissible.

Even if we accept $\left(B^{\prime \prime}\right)$, we have no reason to accept ( $\left.A^{\prime \prime}\right)$. It may be possible to enhance guidance, reduce error and combat abuse only at the cost of liability to-and imposition of-impermissible punishments. That this may be so was one lesson of the pharmaceutical example discussed in section II. It does not follow that law-makers must intend that these punishments be imposed. Their intention may be to bring about the enhancements and reductions I just mentioned. It is true that, in the real world, those who criminalize in pursuit of these aims know it is all but inevitable that some impermissible punishments will be imposed. But we do not intend everything we know will result from our actions. ${ }^{46} \mathrm{We}$ intend a result only if we take that result to count in

\footnotetext{
45 The non-abolitionist may, of course, claim that there are other effects of criminalization that render it impermissible. I turn to some possible effects below.

${ }^{46} \mathrm{I}$ do not intend to wear out my shoes by walking around in them. But I know it will happen.
} 
favour of the action in question. ${ }^{47}$ Law-makers with the aforementioned aims need not take the prospect of impermissible punishment to count in favour of criminalization. Indeed, they may take it to count firmly against, while continuing to think that criminalization is justified by the goods mentioned at the beginning of this paragraph. This is enough to show that law-makers who create liability to impermissible punishment need only see its imposition as a regrettable side-effect of criminalization.

What about the suggestion that liability to impermissible punishment uses those who are impermissibly punished? Everything depends, of course, on what it is to use people. We can distinguish between two views. ${ }^{48}$ On one view, whether we use people depends on our intentions: $\mathrm{V}$ is used only if affecting $\mathrm{V}$ is our means of achieving some end we have chosen to pursue. On a second view, whether we use people depends on their causal role: if subtracting $\mathrm{V}$ from the situation would prevent us achieving some valuable consequence, then $\mathrm{V}$ is used by those who bring that consequence about by affecting $\mathrm{V}$. If the first view is correct, $\left(\mathrm{A}^{\prime \prime}\right)$ is false for the reasons given in the previous paragraph. If the second view is correct, $\left(\mathrm{A}^{\prime \prime}\right)$ is also false. In the pharmaceutical example, it is expert manufacturers who are made liable to punishments that cannot permissibly be imposed. Some of them, we can assume, will be punished. We saw already that law-makers have reason to bring all this about because of the value of the rules that make expert manufacturers liable to punishment. If these manufacturers ceased to exist-if we subtracted them from the legal system - the value of those rules would not disappear. The rules would continue to be good for non-expert manufacturers: they would make fewer errors, benefit from clearer guidance, and be less susceptible to official abuse. In fact, rather than eliminating our reasons to criminalize, subtracting the experts would eliminate the main reason not to - it would eliminate the very people whose impermissible punishment counts against the authoritative list. It follows that expert manufacturers are

\footnotetext{
${ }^{47}$ We might do so because the result is one of our ends, or because it is our chosen means of bringing one of those ends about. Some claim that we also intend results that we know will happen, and which are sufficiently 'close' to those we take to count in favour of our actions. The idea of 'closeness' is notoriously difficult to unpack. But on any view, criminalization and punishment are too distant. They are different acts, typically carried out by different agents, at different points in time.

${ }^{48}$ For this distinction, see A Walen, Transcending the Means Principle, 33 Law and Philosophy 427 (2014).
} 
not used by law-makers in the pharmaceutical example. This is enough to show that we should reject $\left(\mathrm{A}^{\prime \prime}\right)$.

I conclude that (A) and (B) cannot deliver (C) when references to impermissible punishment are interpreted in the fact-relative sense. Here is an alternative:

Reason-relative sense: punishments are impermissible in virtue of the fact that they are not imposed for the reason that the conditions of permissible punishment are met.

Assume again that (W) and (D) identify two such conditions. Punishments are impermissible in the reason-relative sense if punishers do not punish for the reason that the person punished acted wrongfully and deserves punishment. ${ }^{49}$ (A) then holds that if people are made liable to punishment for conduct that is not wrongful or deserving of punishment, offenders will be impermissibly punished because they will be punished for the wrong reasons.

It may help to compare this second version of the argument with the one generated by the fact-relative sense. To see the difference, imagine legislation that criminalizes both actions for which people are permissibly punished—say, possessing a dagger with intent to kill-and actions for which people are not permissibly punished—say, safely possessing a dagger. The statute criminalizes both by simply criminalizing all instances of possession. The fact-relative version of the argument holds that it is impermissible to create this crime because of the punishments that will be imposed on those who safely possess. These people, we can assume, do not deserve punishment. The reason-relative version holds that it is impermissible to create the crime because no punishments will be imposed for the reason that B possessed with intent to kill. Because this intention is no part of the definition of the crime, it will not be the reason judges punish offenders. Instead offenders will simply be punished for possessing a dagger. And this, so the argument goes, is to punish for the wrong reasons.

\footnotetext{
${ }^{49}$ To be clear, it is not enough to make punishment permissible in this sense that the punisher mistakenly believes that tokens of some act-type are wrongful and deserving of punishment. Permissible punishment is imposed for act-types that are believed to be, and actually do, satisfy (W) and (D).
} 
So interpreted, the truth of (A) depends on a factual claim about why judges punish. Is this factual claim true? Not in the legal systems I know of. In those legal systems, sentencing judges are permitted to, and frequently do, take account of morally salient facts about the offender's conduct that do not show up in the definition of the crime. ${ }^{50}$ They may, and frequently do, punish offenders because of these morally salient facts. So it does not follow from the fact that people are liable to punishment for conduct that is morally innocuous, that they will be punished because this is what they did. Judges may punish possessors partly because of their intent to kill, even if this intention is no part of the definition of the crime. If they do, (A) — as we are interpreting it here-is false. ${ }^{51}$

It might be said in reply that whether or not this is what judges do in practice, it remains an unacceptable practice that ought to be eliminated. I return to this reply in due course. Let us assume in the meantime that the factual claim is true: let us assume that if we criminalize ping, people will be punished for having $\varphi$ ed. We must now ask a more basic question: we must ask why motivating reasons matter to the permissibility of punishment, such that those who punish for certain reasons punish impermissibly. We already accepted that motivation matters to what counts as a punishment. A punishes B only if A acts for the reason that (i) A's action will harm B, and (ii) B violated some norm. Our question is why permissible punishments must satisfy an additional condition: why must A also be motivated by the fact that B's conduct satisfies (W) and (D)?

Much depends here on why (W) and (D) are conditions of permissible punishment in the first place. On one view, there is decisive reason not to punish when these conditions are not satisfied, but satisfaction of (W) and (D) is not itself a reason to punish. These conditions merely constrain our pursuit of those goods-like the prevention of harm-

\footnotetext{
${ }^{50}$ Consider, for instance, the list of aggravating factors drawn up by the Sentencing Council for England and Wales: https://www.sentencingcouncil.org.uk/explanatory-material/item/aggravating-and-mitigatingfactors/.

51 True, many offenders will have no intention to kill. But we already saw that prosecutors and judges may exercise discretion to ensure that these offenders are not punished. And we saw that even if some offenders will be impermissibly punished, it does not follow-at least for the non-abolitionist-that criminalization is by that very token impermissible.
} 
that justify punishment. Call this instrumentalism. If instrumentalism is true, it is false that judges should punish for the reason that (W) and (D) are satisfied. This is no reason to punish at all. Instrumentalists might claim that judges permissibly punish only if they punish for the reason that this will prevent harm. But this does nothing to support (A): there is no reason to think that if we criminalize conduct that does not satisfy (W) or (D), judges will not punish for harm-preventive reasons.

On a rival view, the goods that justify punishment are found in a different place. The fact that punishment will achieve retributive justice is itself a reason to punish, and there is sufficient reason to punish only if this good is achieved by punishment. Call this retributivism. If this is our view, it is plausible to think that permissible punishments must indeed be imposed for the reason that (W) and (D) are met. And this is indeed what Moore claims:

To achieve retributive justice, the punishment must be inflicted because the offender did the offence. To the extent that someone is punished for reasons other than that he deserves to be punished, retributive justice is not achieved. ${ }^{52}$

Moore makes two different claims here. It is the second that is of interest to us here. Call it the motivational thesis. That thesis-when combined with retributivism-offers us one answer to the question posed above. If permissible punishments must achieve retributive justice, and retributive justice is achieved only if punishment is imposed for reasons of desert, then punishment is permissible only if it is imposed for the reason that B's conduct satisfies (W) and (D). ${ }^{53}$

We can now return to premise (A) of the argument under discussion. According to that premise, if people are made liable to impermissible punishment then impermissible punishments will be imposed. We are considering the claim that those punishments will be impermissible because they will be imposed for the wrong reasons. The previous paragraph gave us one way to defend that claim. Recall our assumption that, if we criminalize ping, people will be punished for having ped. Now imagine that ping is not wrongful, and does not make one deserving of punishment. If retributivism is true,

\footnotetext{
${ }^{52}$ MOORE, supra note 13, at 28.

${ }^{53}$ Assuming, with Moore, that to deserve punishment one must have acted wrongfully.
} 
permissible punishments must achieve retributive justice. If the motivational thesis is also true, punishing people for the reason that they ped will not achieve retributive justice. All punishments imposed for ping will be impermissible.

One way to challenge this defence of (A) is to challenge retributivism itself. ${ }^{54}$ Another is to challenge the motivational thesis. We can see one reason to doubt that thesis by returning to self-defence. Imagine a legal system in which self-defence is available only to those who use force to ward off imminent threats. ${ }^{55}$ Imagine B is punished for murder, and that murder is committed only by intentional killers who, inter alia, did not act in selfdefence. Not everyone who commits this crime deserves punishment: those who use necessary and proportionate force to ward off non-imminent threats are morally justified in what they do. What makes killers deserving of punishment is that they killed without moral justification. In our imagined legal system, those who are punished for having committed murder are not punished for this reason. They are punished for violating the rules constitutive of the crime of murder, some violations of which do-and some of which do not-make one deserving of punishment. Does it follow-as the motivational thesis implies - that all the punishments imposed for murder in this system fail to achieve retributive justice? Does it follow—as it does when we add retributivism- - that all these punishments are impermissible? This, it seems to me, is hard to believe. Take a case in which B intentionally kills $\mathrm{C}$, is punished for murder, and is obviously morally culpable. It is hard to believe that justice is not done in this case, simply because B would have been denied a defence had B used necessary and proportionate force to ward off a

\footnotetext{
${ }^{54}$ For a range of challenges, see VICTOR TADROS, THE ENDS OF HARM (2012), at 60-87.

${ }^{55}$ I already mentioned that this is true in English law.
} 
non-imminent threat. It is even harder to believe that B's punishment is impermissible for this reason. ${ }^{56}$

One might try to rescue the motivational thesis by distinguishing between offences and defences. One might say that while overinclusive offences are incompatible with retributive justice, underinclusive defences are not. ${ }^{57}$ This might be so because-as Moore suggests in the first sentence of the above quotation-punishment is imposed for the commission of an offence. ${ }^{58}$ This thought, however, returns us to abolitionism. Remember that, according to the motivational thesis, B must be punished for the reason that he deserves punishment. Otherwise, B's punishment is retributively unjust, and-for retributivistsimpermissible. But in all legal systems with general defences-like self-defence or duress-we do not deserve punishment merely because we committed an offence. ${ }^{59}$ So if all punishments are imposed for offences, and the motivational thesis is true, all criminal punishment in these legal systems is unjust and impermissible. According to the punishment thesis, it is permissible to criminalize ping only if the conditions of permissible state punishment are met once ping is criminalized. If those conditions are never met in a given legal system, criminalization is never permissible.

\footnotetext{
${ }^{56}$ One might reply that the motivational thesis can be weakened. It might be permissible to punish people for $\varphi$ ing if a certain percentage of those who $\varphi$ will be deserving of punishment. It is not clear, however, that this suggestion can be made to work. What percentage is required? 50? 75? And how can we know when we criminalise what the percentage of deserving offenders will turn out to be? Everything depends on the dispositions of legal subjects, as well as on the scenarios in which they find themselves. It is not clear that the motivational thesis, so understood, can usefully figure among the conditions of permissible criminalisation.

${ }^{57}$ By over and underinclusive here, I mean over and underinclusive relative to the limits set by (W) and (D). The safe possession offence described above is an overinclusive offence. The defence of self-defence described above is an underinclusive defence.

58 See supra note 52.

${ }^{59}$ Recall the distinction, drawn in section I, between offences and crimes. An action is a crime only if it is both a criminal offence and no defence is available to those who so act.
} 
Let us grant that I am wrong about this, and that if people are punished for offences, the truth of the motivational thesis does not entail abolitionism. It remains the case that if this is why people are punished, (A) is false. To see why, consider the offences of murder and robbery. If there are any offences for which it is permissible to impose punishment, these are presumably on the list. Now imagine that defences like self-defence and duress are eliminated. This makes people criminally liable for many acts that are neither wrongful nor deserving of punishment. ${ }^{60}$ But, ex bypothesi, it does nothing to alter the reasons for which punishments are imposed, because all criminal offences-including murder and robbery-are left untouched. Changes in liability rules that do not alter judges' reasons for punishing cannot make punishments impermissible in the reasonrelative sense. So if people are punished for offences, and this does not entail abolitionism, liability can extend (via the defences) beyond (W) and (D), without the extension rendering any punishment impermissible in the relevant sense. Recall that according to (A), if people are made liable to punishment for conduct that is not wrongful or deserving of punishment, offenders will be impermissibly punished because they will be punished for the wrong reasons. This, we have now seen, need not be the case.

We have been discussing the reason-relative sense of impermissible punishment, in an attempt to find a way to deliver on the argument made up of (A)-(C). So far, we have been unsuccessful. In the course of the discussion I postponed the following thought for further consideration: perhaps it is unacceptable for judges to take morally salient facts into account when punishing $B$ if these facts form no part of the crime at hand. If certain facts make B's conduct wrongful and deserving of punishment, perhaps they should be taken into account by judges only if they feature in the definition of the crime. This thought suggests a third and final account of what makes punishment impermissible:

Evidence-relative sense: punishments are impermissible in virtue of the fact that $\mathrm{B}$ is not entitled to require proof at trial that the conditions of permissible punishment are met.

\footnotetext{
${ }^{60}$ Committing murder in self-defence is not wrongful. Committing robbery under duress is not deserving of punishment.
} 
There are two ways in which $\mathrm{B}$ can require the prosecution — if they wish to convict— to prove that B's conduct has particular properties. B can require proof of offence elements by pleading not guilty. B can require proof of defence elements by proving to the required standard that her conduct satisfied those elements. If the properties that make B's conduct wrongful and deserving of punishment do not figure in offences or defences, B cannot require that those properties be proved at trial. B's punishment is then impermissible in the evidence-relative sense. We can again plug this into the argument from (A)-(C). So interpreted, (A) holds that if people are made liable to punishment for conduct that is not wrongful or deserving of punishment, offenders will be impermissibly punished because they will not be entitled to require proof of wrongfulness or desert.

Why think that punishment is permissible only if those punished had this entitlement? One answer points us back to the fact-relative sense of impermissible punishment. According to that answer, there is an acceptable ratio of punishments that are permissible in the fact-relative sense to punishments that are impermissible in that sense. Let's say that an acceptable ratio is 10:1. That ratio, according to the answer under discussion, is delivered only if B is entitled to have it proved that B's conduct satisfied (W) and (D). The obvious response to this last claim is that we need empirical evidence of its truth. We cannot simply assume that, in the pharmaceutical example introduced in section II, only the first of the responses I considered would generate a ratio of 10:1. Perhaps the ratio would otherwise be lower, and opting for the authoritative list would bring it up to 10:1. Perhaps it would otherwise be higher, and the list would bring it down. I suggested earlier that this might happen if finders of fact would be overzealous in finding that manufacturers who took due care had failed to do so. Such manufacturers might be protected against conviction if their ingredients were not on the list. I have no evidence for this speculation. But nor is there empirical evidence to the contrary. In its absence, we have no reason to accept that the 10:1 ratio-or any other-supports the entitlement under discussion. ${ }^{61}$

\footnotetext{
${ }^{61}$ Ratios of the kind discussed in the text are often used to defend particular standards of proof. For criticism of this reliance in the absence of empirical evidence, see Larry Laudan, Is It Finally Time to Put Proof Beyond a Reasonable Doubt' Out to Pasture?, in THE ROUTLEDGE COMPANION TO PHILOSOPHY OF LAW (Andrei Marmor ed., 2012).
} 
Let us turn to a second answer. Some writers argue that the criminal trial is a process in which B is called to account for criminal conduct of which B is reasonably suspected. This process of calling to account is one element of a wider communicative exchange with $\mathrm{B}$ that includes the condemnation expressed by criminal punishment. ${ }^{62}$ It might be argued that this process of communication fails if $\mathrm{B}$ is not called to account for conduct that satisfies (W) and (D). It might be argued that this explains why B is entitled to require proof that his conduct satisfies those conditions.

Whatever one thinks of this communicative picture of criminal proceedings, the penultimate sentence of the above argument is too dramatic. We are accountable for, inter alia, breaching duties we owe to one another. If I am rude to you, I owe you an explanation. That explanation might justify or excuse what I did. Now I already observed that many legal systems restrict the range of moral justifications and excuses that count as justifications or excuses in law. And I argued that there are sometimes good reasons why this is the case-why the fact that I am an expert manufacturer, or used force to repel a non-imminent threat, is not an available defence in some systems of criminal law. It is hard to believe that wherever these rules exist, they render the criminal process a comprehensive communicative failure. People are still called to account for conduct for which they owe an account of themselves (such as intentional killing). Many justificatory and excusatory accounts remain legally relevant at trial (including the fact that one killed in self-defence against an imminent attack). ${ }^{63}$ We can accept that the exclusion of some such arguments is suboptimal in communicative terms. But communicative success, I have just suggested, comes in degrees. I already argued that there are goods which sometimes count in favour of extending the criminal law beyond the limits set by (W) and (D). These include preventing harmful and wrongful conduct. We can accept that extension brings with it a degree of communicative failure. But unless we have good reason to think that optimizing communication always has lexical priority, its value cannot establish the existence of the entitlement under discussion: it cannot show that B

\footnotetext{
${ }^{62}$ The most well-known defender of this view is Antony Duff. For a recent statement of his views, see R.A. Duff, Relational Reasons and the Criminal Law, in OXFORD STUDIES IN PHILOSOPHY OF LAW: VOLUME 2 (Les Green and Brian Leiter eds., 2013).

${ }^{63}$ And the rest can be offered by $\mathrm{B}$ at the sentencing stage.
} 
is always entitled to proof of wrongfulness and desert. And if B is not always so entitled, it has not been shown that whenever people are liable to punishment for conduct that is not wrongful or deserving of punishment, offenders will be punished impermissibly. (A), as we are interpreting it here, does not hold true. The argument from (A) to (C) again fails to go through.

Section II introduced the following argument for the punishment thesis:

(1) To criminalize $\varphi$ ing is to create liability to state punishment for $\varphi$ ing;

(2) It is permissible to create liability to state punishment for ping only if it is permissible for the state to punish people for $\varphi$ ing;

(3) It is permissible to criminalize ping only if it is permissible for the state to punish people for $\varphi$ ing.

The previous section considered an instrumental argument for (2). The present section considers an intrinsic argument—one that does not depend on the effects of making pers liable to state punishment. The argument runs as follows:

(D) To announce that people are liable to state punishment for ping is to conditionally threaten people with punishment for $\varphi$ ing; ${ }^{64}$

(E) It is permissible to conditionally threaten B with Y only if it is permissible to do $\mathrm{Y}$ to $\mathrm{B}$;

(F) Therefore, it is permissible to make people liable to state punishment for $\varphi$ ing only if it is permissible for the state to punish people for $\varphi$ ing.

One challenge to this argument focuses on (E). Mitch Berman writes that if it is

\footnotetext{
${ }^{64}$ It is frequently claimed that to criminalize $\varphi$ ing is, inter alia, to threaten to punish those who $\varphi$. See e.g. A.P. SIMESTER AND A. VON HIRSCH, CRIMES, HARMS AND WRONGS (2011), at 6; TADROS, supra note 54, at 269; ANDREW ASHWORTH, POSITIVE OBLIGATIONS IN CRIMINAL LAW (2014), at 33 .
} 
impermissible to $\mathrm{Y}$, it is ordinarily impermissible to conditionally threaten to $\mathrm{Y}^{3}{ }^{65}$ So Berman thinks that $(\mathrm{E})$ admits of exceptions. He mentions nuclear deterrence as one 'rare' case in which such an exception might arise. I will not pursue this possibility here. I will grant for the sake of argument that (E) is true. I will instead argue that (D) is false.

To make the argument, it will help to contrast $(E)$ with $(G)$ :

(G) Ceteris paribus, it is permissible to conditionally warn B about $\mathrm{Y}$ even if it is impermissible to do Y to B.

(G) is intuitively plausible. While it is impermissible to threaten to put a bomb in a shopping mall, it is permissible, ceteris paribus, to warn shoppers that there is such a bomb. This is so even if one put the bomb in the mall oneself. It may well be the case that we have stronger reasons to warn others that they may be harmed impermissibly than we have to warn people that they may be harmed permissibly. ${ }^{66}$ The same cannot be said of threats. The fact that setting off the bomb is impermissible does not give me stronger reason to threaten to do it. All else being equal, it is worse to threaten people with the impermissible than to threaten them with the permissible, so there are stronger reasons not to do the former. If (E) is correct-and we are assuming here that it is-those reasons are not only stronger but also decisive.

Why should threats and warnings differ in these ways? We cannot answer without saying something about what conditional threats and conditional warnings are. The two types of speech-act have some things in common. Consider:

Unwelcome: A communicates to $\mathrm{B}$ that $\mathrm{Y}$ may happen if $\mathrm{B} \varphi s$, where $\mathrm{Y}$ is something unwelcome to $\mathrm{B}^{67}$

If $\mathrm{X}$ is not unwelcome to $\mathrm{B}, \mathrm{A}$ 's speech-act may be an offer or a promise, but it cannot be a warning or a threat. Now consider:

\footnotetext{
${ }^{65}$ Mitchell Berman, Blackmail, in THE OXFORD HANDBOOK OF PHILOSOPHY OF CRIMINAL LAW (John Deigh and David Dolinko eds., 2011), at 37.

${ }^{66}$ This will be the case if it is worse for someone to be impermissibly harmed than harmed permissibly.

${ }^{67}$ Or which A believes to be unwelcome.
} 
Control: A has some control over the likelihood of Y happening if B $\varphi s$.

Prevention: A intends to prevent B ping by communicating that $\mathrm{Y}$ may happen if $\mathrm{B}$ $\varphi s$.

Joseph Raz claims that threats are speech-acts of which Unwelcome, Control and Prevention are true. He also claims that the last of the three distinguishes threats from warnings. ${ }^{68}$ But there are warnings that satisfy Prevention as well as Unwelcome and Control. Imagine that at the beginning of each academic year, Bill informs his students that if they make certain errors their exam scripts will receive poor marks. These are the marks that are deserved by scripts that contain such errors. Bill gives his students this information partly in order to prevent them submitting error-strewn scripts. Poor marks are bad for them, and Bill-who is to mark their exam-has control over whether they receive them. Yet Bill does not threaten his students when he tells them the marks they will deservedly receive if they submit poor essays.

What else might distinguish threats from warnings? We can identify a more promising answer by considering a pair of cases helpfully juxtaposed by William Edmundson: ${ }^{69}$

Greenawalt's Moralistic Informer: A learns that B is abusing drugs. A believes that B's drug abuse is wrongful and therefore proposes to B that A will tell B's parents unless B stops.

Wertheimer's Greedy Informer: A learns that B is abusing drugs. Drug abuse doesn't matter to A, but making money does. A therefore proposes to $\mathrm{B}$ that $\mathrm{A}$ will tell B’s parents unless B pays A $£ 100$ by Tuesday.

Edmundson writes that while the Moralistic Informer's proposal is a warning, the Greedy Informer's is a threat. His explanation is that 'the Moralistic Informer's informing is an already impending consequence of B's conduct'. ${ }^{70}$ Why is this so? Edmundson does not mean, of course, that the Moralistic Informer will inform come

\footnotetext{
${ }^{68}$ JOSEPH RAZ, THE MORALITY OF FREEDOM (1986), at 36.

${ }^{69}$ WILLIAM EDMUNDSON, THREE ANARCHICAL FALLACIES (1998), at 113.

${ }^{70} I d$.
} 
what may. What he means, I suggest, is that the Moralistic Informer-being genuinely moralistic - already takes herself to have good reasons to inform if B takes drugs. These are reasons A takes to exist independently of her speech-act. If B were to take drugs, A would tell B's parents for these reasons. True, the Moralistic Informer's speech-act is intended to communicate her intentions to B-and to thereby influence B's behaviourbut it is not intended to create new reasons for the Moralistic Informer to inform. She has no need, we might say, of such reasons.

Things are different in the case of the Greedy Informer. She does not take herself to have independently existing reasons to inform. She does not, after all, care about drug abuse, so her informing is not 'already impending' in Edmundson's sense. Why, then, might she inform on B if B does not pay? Kent Greenawalt's answer is that she might do so 'to stick to [her] word'. ${ }^{71}$ Now one can stick to one's word only if one's word is something one has given. And to give one's word is not merely to report that one will do $\mathrm{Y}$ because one thinks there is already reason to do so; it is to commit oneself to doing Y by communicating that one will. One might ask why the Greedy Informer would commit herself to informing on $\mathrm{B}$. One answer is that this helps lend credibility to her proposal. If $\mathrm{B}$ can see that $\mathrm{A}$ takes herself to have no reason to inform if $\mathrm{B}$ will not pay, $\mathrm{B}$ has no reason to give A the money. If A's greed becomes transparent, A cannot point to independently existing reasons to inform. But she can commit herself to informing by giving her word that she will. By making this commitment, A makes it rational for her to inform on $\mathrm{B}^{72}$ And because A makes her commitment precisely by communicating it to B, A gives B reason to believe A will inform on B even if her greed is transparent. A thereby makes it more likely that she will get her money.

These remarks suggest that conditional threats differ from conditional warnings in the following way. Threats are speech-acts that, inter alia, communicate the speaker's

\footnotetext{
${ }^{71}$ Kent Greenawalt, Criminal Coercion and Freedom of Speech, 78 Northwestern University Law Review 1081 (1983), at 1098 .

${ }^{72} \mathrm{I}$ assume here that if one commits oneself to a course of action, it is rational to pursue that course even if one's commitment does not successfully create reasons to pursue it. This is to follow Parfit in distinguishing between that which it is rational to do, and that which one in fact has reason to do. See DEREK PARFIT, ON WHAT MATTERS: VOLUME 1 (2011), ch. 5.
} 
intention to create reasons for herself. ${ }^{73}$ These are reasons for A to do Y if B $\varphi s$. Such reasons are dependent on-because they are a product of - the threatener's speech-act. Warnings are speech-acts that communicate the existence of independently existing reasons. ${ }^{74}$ These are reasons $Y$ gives $B$ not to $\varphi$. Such reasons would exist even if the warner's speech-act had not occurred.

One advantage of this analysis is that it helps to explain why (E) and (G) should seem plausible. Recall that according to $(\mathrm{E})$, it is impermissible to conditionally threaten $\mathrm{B}$ with $\mathrm{Y}$ if it is impermissible to do $\mathrm{Y}$ to $\mathrm{B}$. If $\mathrm{Y}$ is impermissible, there is decisive reason not to do Y. According to the above analysis, to threaten to do $\mathrm{Y}$ is to commit oneself to doing so, and to thereby make it rational for one to do Y. In the case of a threat to do the impermissible, one's threat makes it rational for one to do what one has decisive reason not to do. This is to use one's capacity for rational action against itself. Raz argues that the telos of that capacity-its point or purpose-is to improve our conformity to the reasons that apply to us as agents. ${ }^{75}$ Those who threaten to act impermissibly use that capacity for the opposite end. They commit themselves to actions they have decisive reason not to perform. In doing so, they use their rational capacities to hinder, not improve, their conformity to reasons. When the reasons in question are moral reasonsas they must be if questions of permissibility are to arise at all-a commitment of this kind is itself morally wrongful: we ought not to use a capacity that exists to help us conform to moral reasons to hinder our own conformity to those very reasons.

So much for (E). According to $(\mathrm{G})$, it is permissible—ceteris paribus — to conditionally warn $\mathrm{B}$ about $\mathrm{Y}$ even if it is impermissible to do $\mathrm{Y}$ to $\mathrm{B}$. We have seen that warnings do not commit the speaker to doing Y. They therefore lack the objectionable feature discussed in the previous paragraph. Instead, they draw the listener's attention to a likelihood that exists independently of them ${ }^{76}$ — the likelihood that $\mathrm{Y}$ will occur if the listener $\varphi s$. The function of warnings is thus not to change anyone's normative position.

\footnotetext{
${ }^{73}$ Similar conclusions to these are reached in Grant Lamond, Coercion, Threats and the Purzle of Blackmail, in HARM AND CULPABILITY (A.P. Simester and A.T.H. Smith eds., 1996).

${ }^{74}$ Or what the speaker claims to be such reasons.

${ }^{75}$ Joseph Raz, The Problem of Authority: Revisiting the Service Conception, 90 Minnesota Law Review 1003 (2006), at 1018.

${ }^{76} \mathrm{Or}$ is claimed by the speaker to exist independently.
} 
It is to better inform those warned about the relative merits of the courses of action open to them. Where the information is accurate, the person warned has greater control over the shape of her own life-she is less likely to be ambushed by demerits of which she was unaware. This remains the case (and if impermissible acts are less predictable, it may be especially the case) when the action of which B is warned is itself impermissible. It is true, of course, that if $\mathrm{Y}$ is impermissible, and the likelihood of it occurring is within the control of $\mathrm{A}$, then $\mathrm{A}$ should exercise her control to reduce or eliminate that likelihood. It does not follow that in cases in which A will not do this, she should not warn B. Ceteris paribus, this is not only morally permissible-as (G) claims-but morally required. Yet it remains the case that if $\mathrm{A}$ refuses to eliminate the aforementioned likelihood, she should not threaten B. This is, of course, just what (E) says.

This section began with the following argument:

(D) To announce that people are liable to state punishment for ping is to conditionally threaten people with punishment for $\varphi$ ing;

(E) It is permissible to conditionally threaten B with $\mathrm{Y}$ only if it is permissible to do Y to $\mathrm{B}$;

(F) Therefore, it is permissible to make people liable to state punishment for ping only if it is permissible for the state to punish people for ping.

Having explored what it is to make a conditional threat, and why (E) might be true of such threats, we can now turn to (D). Does announcing that pers are liable to state punishment conditionally threaten pers with punishment? If I am right so far, this depends on the function the announcement is meant to fulfil. If the announcement is meant to create new reasons for the state to punish pers, that announcement is a threat. If it is meant to draw attention to the fact that pers may be punished for independently existing reasons, the announcement is a warning. We cannot here identify the actual intentions of those who created any given criminal offence. But we can ask what the intention of law-makers ought ideally to be. If law-makers ought not to threaten potential offenders, we can at least say this: in the system of criminal law we should want, (D) is false.

Here is one way to put the question that remains: should state punishment be like the informing of the Greedy Informer, or should it be like that of the Moralistic Informer? 
To take the former view is to hold that state punishment should be imposed on pers (at least partly) because the state announced that it might punish them if they $\varphi$ ed. This view implies that judges should sentence defendants to imprisonment (partly) because the state announced that this is what they are empowered to do. This view is doubly problematic. First, judges are often empowered to grant those convicted an absolute discharge. In cases of this kind, the state explicitly announces both that the judge may punish pers and that she may not. The state's announcement does not say anything about what the judge should do. It is thus hard to see why it should itself be taken to be a reason to punish. Second, and more importantly, the fact that the state announced that pers are liable to punishment is the wrong kind of reason for judges to punish pers. Imagine I cut off your arm. In the legal system we should want, I would be punished because I deserve it, or because I have a duty to protect others against harm, or for some other independently existing reason. I would be punished, in brief, for the reasons that made it worth making me liable to punishment in the first place. I would not be punished because the liability was in fact announced. ${ }^{77}$

It is worth noting that the independently existing reasons I have mentioned need not exist independently of the law. There may be good things-including valuable forms of co-ordination - that can only be achieved by legal norms, and that can only be achieved if those who violate those norms are at least sometimes punished. By announcing that violators are liable to punishment, the state may be able to achieve these goods while imposing fewer punishments. Some may conform to the law because of the announcement. It remains the case that the state's reason to punish violators is not the fact that the announcement was made. It is the fact-already mentioned above-that punishment is necessary to achieve good things, including valuable forms of coordination. The point of the announcement is to draw the attention of potential violators to the likelihood that they will be punished, and to thereby reduce the likelihood of violation. The announcement, in other words, is intended to achieve the same good as the punishments it announces. It is not-or at least it should not be-intended to add to the case for their imposition. If this is correct, the announcement mentioned in (D) is properly equated, not to the informing of the Greedy Informer, but to that of the

\footnotetext{
77 Which is not to say that it would be impermissible to punish for these reasons. That is a further question.
} 
Moralistic Informer. More importantly, it is a warning not a threat. And if it is indeed a warning - at least in the legal system we should want-(D) is false. The argument from (D) to (F) then fails.

The limits of permissible criminalization and the limits of permissible punishment are often discussed interchangeably. Discussions that purport to be about the first topic often imperceptibly become discussions of the second. ${ }^{78}$ If we fail to keep the two topics separate, we will be inclined to slip into thinking that the punishment thesis must be true. If $c$ is a condition of permissible punishment, and if criminalization and punishment are one and the same, $c$ must also be a condition of permissible criminalization. Yet criminalization is not punishment, and it does not entail that anyone will be punished. The punishment thesis cannot be taken for granted. In this paper, I have suggested that it also may not be true. I have not considered every argument that might be used to defend that thesis. But I hope to have made clear that an argument is needed, and to have disposed of some apparently promising contenders. Until a better argument is forthcoming, Moore's new orthodoxy remains a church in need of foundations. We are yet to see why — as Husak would have it —only disreputable theories of criminalization would contemplate criminalizing conduct for which people cannot permissibly be punished. We are yet to see why we should accept the punishment thesis.

\footnotetext{
${ }^{78}$ Even Feinberg, who is more careful than most, sometimes falls into this trap. He begins Harm to Others by claiming that his topic is liberty-limiting principles that apply to criminalization. But he soon writes that his interest is in whether 'criminal sanctions are special enough to require their own liberty-limiting principles' (FEINBERG, supra note 21, at 24). Criminalization is one thing. Criminal sanctions are another.
} 